\title{
Ischemic Insults Direct Glutamate Receptor Subunit 2-Lacking AMPA Receptors to Synaptic Sites
}

\author{
Baosong Liu, ${ }^{1,2,3}$ Mingxia Liao, ${ }^{1,2,3}$ John G. Mielke, ${ }^{1,2,3}$ Ke Ning, ${ }^{1,2,3}$ Yonghong Chen, ${ }^{1,2,3}$ Lei Li, ${ }^{1,2,3}$ Youssef H. El-Hayek, ${ }^{1,2,3}$ \\ Everlyne Gomez, ${ }^{1,2,3}$ R. Suzanne Zukin, ${ }^{5}$ Michael G. Fehlings, ${ }^{1,3,4}$ and Qi Wan ${ }^{1,2,3}$ \\ ${ }^{1}$ Division of Cellular and Molecular Biology, Toronto Western Research Institute, University Health Network, Departments of ${ }^{2} \mathrm{Physiology}$ and ${ }^{3}$ Surgery, \\ and ${ }^{4}$ Institute of Medical Science, University of Toronto, Toronto, Ontario, Canada M5T 2S8, and ${ }^{5}$ Department of Neuroscience, Albert Einstein College of \\ Medicine, Bronx, New York 10461
}

Regulated AMPA receptor (AMPAR) trafficking at excitatory synapses is a mechanism critical to activity-dependent alterations in synaptic efficacy. The role of regulated AMPAR trafficking in insult-induced synaptic remodeling and/or cell death is, however, as yet unclear. Here we show that brief oxygen-glucose deprivation (OGD), an in vitro model of brain ischemia, promotes redistribution of AMPARs at synapses of hippocampal neurons, leading to a switch in AMPAR subunit composition. Ischemic insults promote internalization of glutamate receptor subunit 2 (GluR2)-containing AMPARs from synaptic sites via clathrin-dependent endocytosis and facilitate delivery of GluR2-lacking AMPARs to synaptic sites via soluble $\mathrm{N}$-ethylmaleimide-sensitive factor attachment protein receptordependent exocytosis, evident at early times after insult. The OGD-induced switch in receptor subunit composition requires PKC activation, dissociation of GluR2 from AMPA receptor-binding protein, and association with protein interacting with C kinase-1. We further show that AMPARs at synapses of insulted neurons exhibit functional properties of GluR2-lacking AMPARs. AMPAR-mediated miniature EPSCs exhibit increased amplitudes and enhanced sensitivity to subunit-specific blockers of GluR2-lacking AMPARs, evident at $24 \mathrm{~h}$ after ischemia. The OGD-induced alterations in synaptic AMPA currents require clathrin-mediated receptor endocytosis and PKC activation. Thus, ischemic insults promote targeting of GluR2-lacking AMPARs to synapses of hippocampal neurons, mechanisms that may be relevant to ischemia-induced synaptic remodeling and/or neuronal death.

Key words: ischemia; neuronal death; AMPA receptors; GluR2 subunit; synapse; receptor trafficking

\section{Introduction}

AMPA receptors (AMPARs) mediate fast synaptic transmission at excitatory synapses in the CNS and are heteromeric complexes composed of glutamate receptor subunit 1-4 (GluR1-GluR4) (Hollmann and Heinemann, 1994; Dingledine et al., 1999). In principal hippocampal neurons, AMPARs are primarily of the GluR1/GluR2 and GluR2/GluR3 configuration (Craig et al., 1993; Wenthold et al., 1996). The GluR2 subunit governs a number of properties of heteromeric AMPAR assemblies, including permeability to divalent cations. Whereas AMPARs containing the edited GluR2 subunit are impermeable to divalent cations, AMPARs lacking the edited GluR2 subunit are highly permeable to $\mathrm{Ca}^{2+}$ and $\mathrm{Zn}^{2+}$ (Verdoorn et al., 1991; Geiger et al., 1995). Thus, AMPARs at synapses of hippocampal pyramidal neurons are typically $\mathrm{Ca}^{2+} / \mathrm{Zn}^{2+}$ impermeable.

Activity-dependent AMPAR trafficking is a mechanism criti-

Received Aug. 22, 2004; revised April 9, 2006; accepted April 9, 2006

This work was supported by Heart and Stroke Foundation of Ontario (Q.W.), Canadian Institutes of Health Research (Q.W., M.G.F), and National Institutes of Health Grant NS46742 (R.S.Z.)

Correspondence should be addressed to either of the following: Dr. R. Suzanne Zukin, Albert Einstein College of Medicine, 1300 Morris Park Avenue, Room 607 Kennedy, Bronx, NY 10461, E-mail: zukin@aecom.yu.edu; or Dr. Qi Wan, Toronto Western Research Institute, University of Toronto, 399 Bathurst Street, McLaughlin Pavilion 14-409, Toronto, Ontario, Canada M5T 2S8, E-mail: qi.wan@utoronto.ca.

DOI:10.1523/JNEUROSCI.0567-06.2006

Copyright $\odot 2006$ Society for Neuroscience $\quad$ 0270-6474/06/265309-11\$15.00/0 cal to many forms of synaptic plasticity and remodeling (Carroll et al., 2001). Receptor recycling and synaptic targeting in response to neuronal activity is mediated by interactions of AMPAR subunits with receptor trafficking and anchorage proteins such as AMPA receptor-binding protein (ABP) and protein interacting with $\mathrm{C}$ kinase-1 (PICK1) (Malinow and Malenka, 2002). AMPARs move rapidly between the plasma membrane and intracellular compartments via regulated receptor endocytosis and exocytosis (Malenka and Nicoll, 1999; Malinow et al., 2000; Carroll et al., 2001; Sheng and Lee, 2001). In addition, AMPARs are laterally translocated within the membrane between synaptic and extrasynaptic sites (Borgdorff and Choquet, 2002). Synaptic plasticity is thought to involve alterations in the number and phosphorylation state of postsynaptic AMPARs (Carroll et al., 2001) but may also involve alterations in AMPAR subunit composition (Liu and Cull-Candy, 2000, 2005; Gardner et al., 2005).

Transient global ischemia induces delayed neuronal death, particularly in the hippocampal CA1 (Kirino, 1982; Pulsinelli et al., 1982; Choi, 1995; Zukin et al., 2004). Substantial evidence implicates $\mathrm{Ca}^{2+} / \mathrm{Zn}^{2+}$-permeable, GluR2-lacking AMPARs in ischemic cell death (Tanaka et al., 2000; Zukin et al., 2004). Global ischemia induces downregulation of GluR2 mRNA and protein expression (Pellegrini-Giampietro et al., 1992; Gorter et al., 1997; Opitz et al., 2000; Tanaka et al., 2000; Noh et al., 2005) 
and enhanced AMPAR-mediated $\mathrm{Ca}^{2+}$ and $\mathrm{Zn}^{2+}$ influx in CA1 neurons (Gorter et al., 1997; Yin et al., 2002). Synaptic AMPA currents in post-ischemic hippocampus display pronounced inward rectification and enhanced sensitivity to 1-naphthyl acetyl spermine (Naspm) and Joro spider toxin, channel blockers selective for GluR2-lacking AMPARs (Tsubokawa et al., 1995; Ying et al., 1997; Liu et al., 2004; Noh et al., 2005; Peng et al., 2006). These findings demonstrate the expression of functional $\mathrm{Ca}^{2+} / \mathrm{Zn}^{2+}$ permeable, GluR2-lacking AMPARs at CA1 synapses at 24-48 h after ischemia. Whereas considerable evidence underscores alterations in AMPAR subunit composition and function hours or days after injury, receptor changes at early times after ischemia remain unclear.

Here we show that oxygen-glucose deprivation (OGD), a well established in vitro model of ischemic neuronal injury (Goldberg and Choi, 1993; Ying et al., 1997), directs GluR2-lacking AMPARs to hippocampal synapses at early times after ischemia. OGD promotes internalization of primarily GluR2-containing AMPARs and facilitates delivery of GluR2-lacking AMPARs, leading to expression of functional GluR2-lacking AMPARs at synapses of post-ischemic neurons. These results implicate regulated AMPAR trafficking in ischemia-induced synaptic remodeling and/or neuronal injury.

\section{Materials and Methods}

Hippocampal neuronal culture and OGD treatment. Hippocampal neuronal cultures were prepared from Wistar rats at gestation day 18 (Brewer et al., 1993). Dissociated neurons were suspended in plating medium (Neurobasal medium, 2\% B-27 supplement, 0.5\% FBS, $0.5 \mu \mathrm{M} \mathrm{L-glutamine,}$ and $25 \mu \mathrm{M}$ glutamic acid) and transferred to poly-D-lysine-coated coverslips in $35 \mathrm{~mm}$ Petri dishes. After $3 \mathrm{~d}$ in vitro (DIV), three-quarters of the plating medium was removed and replaced with maintenance medium (Neurobasal medium, B-27 supplement, and $0.5 \mu \mathrm{M}$ L-glutamine). Medium replacement was performed every 3-4 d, and cells were used at 12-15 DIV. To initiate the OGD challenge, cells were transferred to deoxygenated glucose-free extracellular solution (ECS) (in mM: $116 \mathrm{NaCl}$, $5.4 \mathrm{KCl}, 0.8 \mathrm{MgSO}_{4}, 1.0 \mathrm{NaH}_{2} \mathrm{PO}_{4}, 1.8 \mathrm{CaCl}_{2}$, and $26 \mathrm{NaHCO}_{3}$ ), introduced into a specialized, humidified chamber (Plas-Labs, Lansing, MI), and maintained at $37^{\circ} \mathrm{C}$ in $85 \% \mathrm{~N}_{2} / 10 \% \mathrm{H}_{2} / 5 \% \mathrm{CO}_{2}$ for 20 min (Goldberg and Choi, 1993; Ying et al., 1997). Neurons were removed from the chamber, transferred to maintenance medium, and returned to the incubator. For "sham" treatment, control cultures were transferred to the ECS (in mm: $116 \mathrm{NaCl}, 5.4 \mathrm{KCl}, 0.8 \mathrm{MgSO}_{4}, 1.0 \mathrm{NaH}_{2} \mathrm{PO}_{4}, 1.8 \mathrm{CaCl}_{2}, 26$ $\mathrm{NaHCO}_{3}$, and 33 glucose), introduced into the humidified chamber, and maintained at $37^{\circ} \mathrm{C}$ for $20 \mathrm{~min}$ in $95 \% \mathrm{O}_{2} / 5 \% \mathrm{CO}_{2}$. After sham treatment, control neurons were transferred to maintenance medium and returned to the original incubator.

Colorimetric assays. Colorimetric assays were performed as described previously (Lu et al., 2001). To label surface GluR1, GluR2, or GluR3 subunits, cells were fixed with paraformaldehyde ( $4 \%$ for $10 \mathrm{~min}$ ) under nonpermeabilized conditions (Lu et al., 2001) and labeled with rabbit anti-GluR1 (Oncogene, San Diego, CA) (Passafaro et al., 2001), mouse anti-GluR2 (Chemicon, Temecula, CA) (Passafaro et al., 2001), or rabbit anti-GluR3 (Chemicon) (Moga et al., 2003) antibody raised against the N-terminal extracellular region (Lu et al., 2001). To label total GluR1, GluR2, and GluR3 subunits, immunolabeling was performed under permeabilized conditions. In brief, cells were fixed with $4 \%$ paraformaldehyde for $30 \mathrm{~min}$, followed by treatment with $0.25 \%$ Triton X-100 for 10 min. Cells were then incubated with the same antibodies, followed by incubation ( $1 \mathrm{~h}$ at room temperature) with horseradish peroxidaseconjugated secondary antibodies (Amersham Biosciences, Baie D'urfe, Quebec, Canada), washed five times with PBS to minimize nonspecific reactivity, and then incubated with $1 \mathrm{ml}$ of HRP substrate $o$-phenylenediamine (Sigma, St. Louis, MO) for 2-5 min. Reactions were stopped with $0.2 \mathrm{ml}$ of $3 \mathrm{~N} \mathrm{HCl}$, and the optical density of the supernatant was read on a spectrophotometer at $492 \mathrm{~nm}$. Analysis was performed on six dishes per group.
Immunofluorescent labeling, image acquisition, and analysis. To examine colocalization of GluRs and synaptophysin, nonpermeabilized control or treated neurons (12-15 DIV) were labeled for surface AMPARs, permeabilized, and relabeled with anti-synaptophysin antibody as described previously (Lu et al., 2001). In brief, nonpermeabilized cells were labeled with rabbit anti-GluR1 (Oncogene or Calbiochem, La Jolla, CA), mouse anti-GluR2 (Chemicon), or rabbit anti-GluR3 (Chemicon) antibodies (Lu et al., 2001) and Alexa Fluor 488 (green fluorescence) secondary antibodies (Invitrogen, Carlsbad, CA). Cells were then permeabilized $(0.25 \%$ Triton $\mathrm{X}-100,10 \mathrm{~min})$ and relabeled with anti-synaptophysin antibody (Sigma or Zymed, San Francisco, CA) and Alexa Fluor 594 (red fluorescence) secondary antibodies (Invitrogen).

Fluorescent-labeled receptors were imaged using a $63 \times$ objective mounted on a Zeiss (Oberkochen, Germany) LSM 510 META confocal microscope as described previously (Beattie et al., 2000; Passafaro et al., 2001). Images were acquired using a Zeiss AxioCam digital camera in the linear range with constant settings and were analyzed using Image Pro Plus analysis software (Media Cybernetics, Silver Spring, MD). Each image was a $z$-series of $6-13$ images, taken at $0.75-\mu \mathrm{m}$-depth intervals. The resultant stack was "flattened" into a single image using a maximum projection. For all experiments, we analyzed fluorescent signal in regions of interest by two methods: (1) we counted immunofluorescent puncta, and (2) we measured average fluorescence intensity per unit area. In al cases, the two methods afford essentially identical results; thus, we present only data obtained by puncta counting. The quantification of fluorescence staining was performed as described previously (Snyder et al., 2001; Ju et al., 2004). For individual experiments, all images in all experiments were analyzed using identical acquisition parameters. During data acquisition and analysis, the investigator was blind to the treatment group. For each experiment, control and treated cells from the same culture preparation were processed and imaged in parallel. In each experiment, neurons were selected randomly under bright-field optics, and fluorescent images of each neuron acquired from a single plane were transferred for analysis.

To assess synaptic localization of GluR1, GluR2, and GluR3, the subunits and synaptophysin images were merged. Puncta were identified as discrete regions of fluorescence more than twofold of background. Images of neuronal processes for each experiment were thresholded to subtract the average background fluorescence in cells labeled with negative control probes. Individual thresholded puncta were counted for every discrete $10 \mu \mathrm{m}$ length of process. The average intensity of fluorescence puncta was also measured. Two or three processes per cell and 20-40 cells from four or five separate cultures each were averaged. The $n$ value refers to the number of cells analyzed.

Hypertonic sucrose, chlorpromazine, and light chain of botulinum toxin type A treatments. To examine the effects of OGD on clathrin-mediated AMPAR internalization, neurons were first treated with hypertonic sucrose (0.45 M, $20 \mathrm{~min}$ ) (Hansen et al., 1993; Lin et al., 2000; Man et al., 2000) or chlorpromazine (7.5 $\mu \mathrm{M}, 30 \mathrm{~min})$ (Wang et al., 1993; Zhu et al., 2005 ) and then subjected to OGD (20 min). Total, surface, and synaptic GluR2 expression was evaluated at $0 \mathrm{~h}$ after insult. To examine the effects of OGD on the delivery of AMPARs to synaptic sites via soluble $\mathrm{N}$-ethylmaleimide-sensitive factor attachment protein receptor (SNARE)-dependent exocytosis, neurons were treated with light chain of botulinum toxin type A (BoNT A) $(1 \mu \mathrm{g} / \mathrm{ml}$; BB Tech, Dartmouth, MA) or heat-inactivated BoNT A (as a negative control) for $30 \mathrm{~min}$, followed by hypertonic sucrose ( $0.45 \mathrm{M}$ for $20 \mathrm{~min}$ ) and then subjected to OGD ( 20 min). Total, surface, and synaptic GluR1, GluR2, and GluR3 expression were evaluated at $0 \mathrm{~h}$ after insult. Drugs and reagents (sucrose, chlorpromazine, and BoNT A) were kept in the culture medium during OGD.

Coimmunoprecipitation and immunoblotting. Coimmunoprecipitation and immunoblotting assays were performed as described previously (Wan et al., 1997a; Liu et al., 2000). Homogenates from control and OGD-treated hippocampal cultures were incubated with anti-adaptin $\beta_{2}$ antibody (Sigma) or GluR2 (Chemicon) in $500 \mu \mathrm{l}$ of $50 \mathrm{~mm}$ Tris- $\mathrm{HCl}$, $150 \mathrm{~mm} \mathrm{NaCl}$, and $0.1 \%$ Triton $\mathrm{X}-100$ for $4 \mathrm{~h}$ at $4^{\circ} \mathrm{C}$. The antibody protein complexes were captured with protein A-Sepharose beads. Proteins were eluted from the beads and subjected to SDS-PAGE and immunoblotting for anti-adaptin $\beta_{2}$ (1:2000; Sigma), GluR2 (1:1000; Chemi- 
A
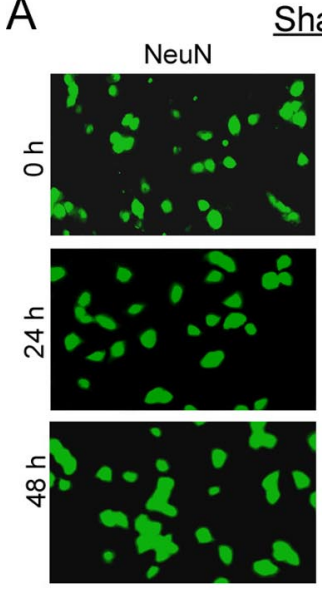

Sham
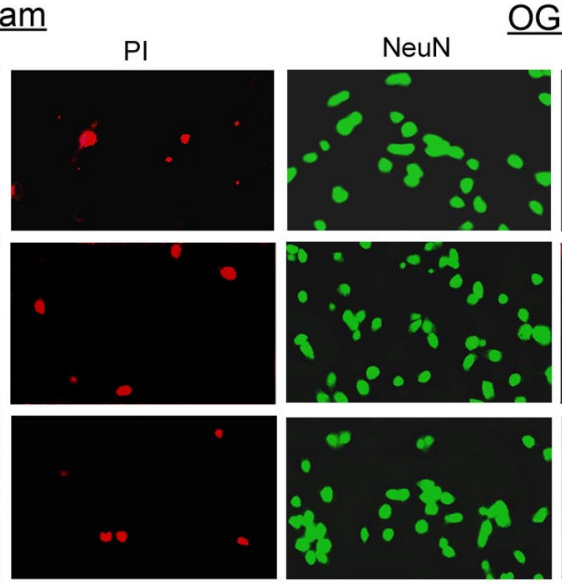

GD

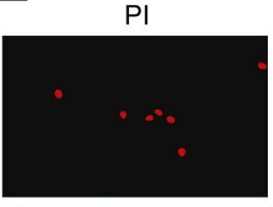

B

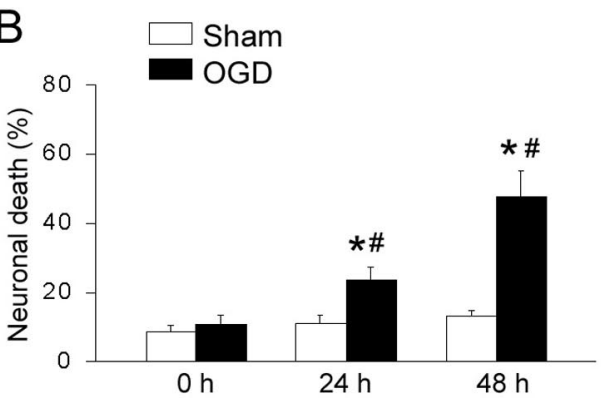

Figure 1. A, Time course of OGD-induced hippocampal neuronal death. Representative images of Pl uptake and staining for the neuronal marker neuronal-specific nuclear protein (NeuN) showing OGD-induced delayed neuronal death in hippocampal cultures at 0,24 , and $48 \mathrm{~h}$. Neurons at 14-21 DIV were subjected to $20 \mathrm{~min}$ OGD. B, Summary data of PI uptake. OGD induced neuronal death, evident at 24 and $48 \mathrm{~h}$ after insult $\left({ }^{*} p<0.05\right.$, difference from sham groups; ${ }^{*} p<0.05$, difference from $0 \mathrm{~h} ;$ sham, $0 \mathrm{~h}, n=$ 236 neurons; $24 \mathrm{~h}, n=217 ; 48 \mathrm{~h}, n=198 ; 0 \mathrm{GD}, 0 \mathrm{~h}, n=241 ; 24 \mathrm{~h}, n=205 ; 48 \mathrm{~h}, n=227)$. Scale bar, $50 \mu \mathrm{m}$.

death, as assessed by propidium iodide (PI) uptake (Fig. 1A). OGD elicited delayed neuronal death, evident at 24 and $48 \mathrm{~h}$ after insult (Fig. $1 A, B$ ) but not at 0 (Fig. 1), 6, 12, or $18 \mathrm{~h}$ after injury (data not illustrated). Together, these findings validate the paradigm (20 min OGD) as suitable for the investigation of insultinduced alterations in AMPAR number and/or subunit composition via regulated receptor trafficking.

To examine the impact of OGD on synaptic localization of GluR2, we assessed juxtaposition of GluR2 labeling with labeling of the presynaptic marker synaptophysin. Under control conditions, numerous small clusters of GluR2 immunofluorescence were detected at the surface of dendrites (Fig. 2A). A substantial proportion of GluR2 clusters colocalized to synaptic sites marked by synaptophysin puncta; similarly, a significant proportion of synaptophysin puncta were juxtaposed to GluR2 clusters (Fig. 2A). OGD significantly reduced the number of GluR2 clusters at synaptic sites, assessed at 0,12 , and 24 h (Fig. $2 A, D, E$ ). To quantify GluR2 total and surface protein expression in intact neurons, we performed colorimetric assays. OGD induced a significant reduction in surface GluR2 expression, assessed at 0, 12, and $24 \mathrm{~h}$ (Fig. 2C) but did not alter total GluR2 protein abundance (Fig. $2 \mathrm{~B}$ ). In contrast, OGD (20 min) did not alter total cellular abundance of GluR1, GluR2,

con), PICK1 (1:1000; Chemicon), or ABP (1:1000; Chemicon), respectively. For subsequent probing of the same membrane, membranes were stripped of antibody and reprobed. Blots were developed using enhanced chemiluminescence detection (Amersham Biosciences). Band intensities were quantified using Image Pro Plus software.

Recording of AMPAR-mediated miniature EPSCs. Recording of miniature EPSCs (mEPSCs) was as described previously (Wan et al., 1997b). Neurons were held under voltage clamp at $-70 \mathrm{mV}$. The patch electrode solution contained the following (in mM): $140 \mathrm{CsCl}$, $2.5 \mathrm{EGTA}$, or 25 BAPTA, $2 \mathrm{MgCl}_{2}$, 10 HEPES, 0.1 spermine, and $4 \mathrm{Na}_{2} \mathrm{ATP}$, pH 7.3 (osmolarity between 300 and $310 \mathrm{mOsm}^{-1}$ ). The extracellular solution was of the following composition (in mM): $140 \mathrm{NaCl}, 1.3 \mathrm{CaCl}_{2}, 5.0 \mathrm{KCl}, 25$ HEPES, 33 glucose, 0.0005 TTX, $0.1 \mathrm{APV}$, and 0.02 bicuculline methiodide, pH 7.4 (osmolarity between 325 and $335 \mathrm{mOsm}^{-1}$ ). AMPARmEPSCs were recorded using an Axopatch 200B amplifier (Molecular Devices, Palo Alto, CA), and at least 200 individual mEPSCs were collected before and after application of Naspm (20 $\mu \mathrm{M}$ for $1 \mathrm{~min}$, applied via bath perfusion). Records were filtered at $2 \mathrm{kHz}$ and analyzed with a Mini Analysis program (Synaptosoft, Leonia, NY).

Statistics. All population data were expressed as mean \pm SEM. Significance was assessed by the Student's unpaired $t$ test or ANOVA and was defined as $p<0.05$.

\section{Results}

OGD reduces GluR2 expression at postsynaptic membrane

To examine whether neuronal insults alter the number and/or subunit composition of synaptic AMPARs via regulated receptor internalization and/or delivery, we subjected cultured hippocampal neurons (14-21 DIV) to 20 min OGD, a relatively mild ischemic insult. To validate this paradigm as an experimental model of delayed neuronal death, we examined the time course of cell or GluR3 subunits, assessed at $0 \mathrm{~h}$ (control, 100; GluR1, $96.7 \pm$ 11.3; GluR2, $97.8 \pm 15.2$; GluR3, $95.9 \pm 11.6$; data were normalized to the corresponding control values; ${ }^{\star} p>0.05$, difference from control; $n=6$ for each group). These findings demonstrate that mild OGD (20 min) reduces synaptic GluR2 number but not total cellular abundance, consistent with regulated receptor trafficking at early times after insult.

In hippocampal neurons, GluR1/GluR2 and GluR2/GluR3 heteromers are the most common AMPAR subtypes (Craig et al., 1993; Wenthold et al., 1996). To investigate whether OGDinduced alterations in synaptic GluR2 number were subunit specific, we examined synaptic and surface expression of GluR1 and GluR3 at 0,12 , and $24 \mathrm{~h}$ after OGD. OGD did not significantly alter the synaptic GluR1 or GluR3 number, assessed as juxtaposition of GluR1/3 clusters to synaptophysin puncta (Fig. $3 A, D, E, H, I)$, nor did it significantly alter GluR1 or GluR3 surface expression, as assessed by colorimetric assay (Fig. $3 C, G$ ). Moreover, total GluR1 and GluR3 subunit abundance were unaltered at all times examined (Fig. $3 B, F$ ). These results indicate that OGD specifically alters surface and synaptic GluR2 but not GluR1 or GluR3 number at hippocampal synapses at early times after insult.

\section{OGD-induced retrieval of synaptic GluR2 is mediated via clathrin-dependent internalization}

Regulated receptor internalization via the clathrin-coated pit pathway is a well established mechanism by which AMPARs are retrieved from synaptic sites in response to neuronal activity 
(Sheng and Lee, 2001). To examine a possible role for the clathrin-mediated pathway in the loss of synaptic GluR2 at early times after ischemia, we performed three experiments. First, we treated neurons with hypertonic sucrose, which disrupts formation of clathrin cages and blocks clathrin-mediated AMPA receptor endocytosis (Hansen et al., 1993; Lin et al., 2000; Man et al., 2000). Hypertonic sucrose $(0.45 \mathrm{M}$, applied for $20 \mathrm{~min}$ before OGD) did not detectably alter constitutive GluR2 expression, as assayed by colorimetric assays (Fig. 4B), but prevented OGD-induced reduction in surface and synaptic GluR2 expression at $0 \mathrm{~h}$ after insult, as assessed by doubleimmunofluorescence staining for the presynaptic marker synaptophysin and GluR2 (Fig. $4 A, C, D, E$ ). Second, we treated neurons with chlorpromazine, a cationic amphiphilic drug that prevents the assembly of clathrin adapter protein AP2 with clathrin-coated pits (Wang et al., 1993; Zhu et al., 2005). Chlorpromazine [7.5 $\mu \mathrm{M}$ applied for $30 \mathrm{~min}$ before insult (Zhu et al., 2005)] similarly abolished the OGD-induced reduction in surface and synaptic GluR2 expression (data not illustrated). Together, these data suggest that OGD-elicited GluR2 reduction at synapses is mediated by clathrin-dependent endocytosis.

Third, we assessed association of the GluR2 subunit with AP2, an adaptor protein of the clathrin complex that binds internalized receptors in clathrin-coated pits in post-ischemic versus control neurons (Schmid, 1997; Man et al., 2000). Protein extracts were subjected to immunoprecipitation with an antibody directed to the adaptin subunit $\beta_{2}$, a key component of the AP2 complex, and GluR2 immunolabeling was performed. In control neurons (Fig. $4 F$, left), a low level of GluR2 coprecipitated with adaptin $\beta_{2}$, indicative of a relatively low rate of constitutive AMPAR internalization. OGD substantially increased the amount of GluR2 that was associated with adaptin $\beta_{2}$ (Fig. $4 F$ ). These data provide additional evidence that GluR2 subunits are internalized via the clathrin-mediated pathway and that OGD promotes receptor internalization by recruiting the GluR2 subunit to the AP2 complex.

\section{OGD facilitates removal of GluR1 and GluR3 subunits from synaptic sites}

Although OGD did not significantly change the number of surface and synaptic GluR1 and GluR3 (Fig. 3), the insult might nevertheless regulate internalization and delivery of these subunits, but to the same extent. To address this possibility, we examined the effect of OGD on GluR1 and GluR3 surface and synaptic expression in neurons pretreated with hypertonic sucrose. In control neurons, hypertonic solution (20 min) did not detectably alter GluR1 or GluR3 surface or synaptic expression (Fig. $5 C, D$, compare first and second bars). However, at $0 \mathrm{~h}$ after OGD insult, an increase in surface and synaptic expression of GluR1 and GluR3 was observed in hypertonic sucrose (Fig. 5), indicat-
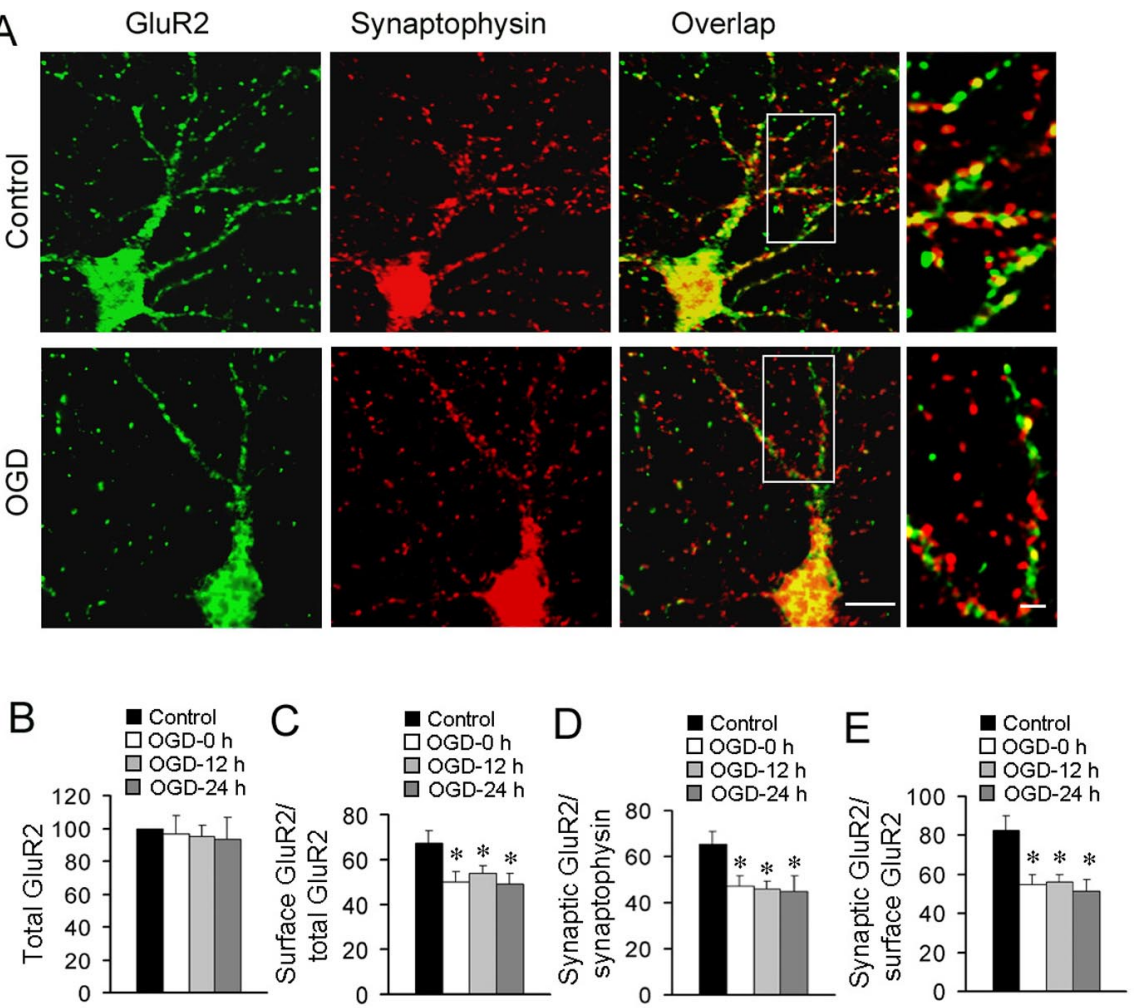

Figure 2. OGD decreases GluR2 surface expression at synaptic sites in cultured hippocampal neurons. $\boldsymbol{A}$, Representative images showing the juxtaposition of surface GluR2 and the presynaptic marker synaptophysin in control and experimental neurons at $24 \mathrm{~h}$ Digher-magnification images correspond to the boxed areas in the lower-magnification images. Scale bars: lowerexpression at 0,12 , and $24 \mathrm{~h}(n=6$ for each group; $p>0.05)$. C, OGD reduces surface GluR2 expression, assessed at 0,12 , and $24 \mathrm{~h}$ a ter insults ( $n=6$ for each group; ${ }^{*} p<0.05$ ). $D$, Quantification of the percentage of synaptophysin-positive synapses containing GluR2 puncta in control and OGD neurons ( $n=33,29,32$, and 26, respectively, per group; ${ }^{*} p<0.05$ ). $\boldsymbol{E}$, Quantification of the percentage of surface GluR2 puncta that are juxtaposed with synaptophysin puncta in control and OGD neurons $(n=29,30,31$, and 26 , respectively, per group; ${ }^{*} p<0.05$ ).

ing that OGD promotes internalization of GluR1 and GluR3 subunits, with no change in the subunit number in the postsynaptic membrane. Similar results were observed at $24 \mathrm{~h}$ after OGD (data not illustrated). We reasoned that OGD might promote insertion of GluR1 and GluR3 subunits in the postsynaptic membrane via exocytosis, a process that masks (or counterbalances) the OGDelicited increase in internalization of GluR1 and GluR3 subunits via clathrin-dependent endocytosis. Together with the observation of OGD-mediated GluR2 internalization (Fig. 4), these data suggest that the ischemic insult may induce endocytosis of GluR2-containing AMPARs (GluR1/GluR2 and GluR2/GluR3 heteromers), the most expressed AMPAR subtype at hippocampal synapses.

\section{OGD promotes synaptic delivery of GluR1 and}

\section{GluR3 subunits}

To examine whether OGD promotes delivery of GluR1 and GluR3 to synaptic sites via SNARE-dependent exocytosis, we took advantage of BoNT A. BoNT A cleaves synaptosomeassociated protein of $25 \mathrm{kDa}$ (SNAP-25) and prevents SNAP-25dependent exocytosis (Montecucco and Schiavo, 1995) and inhibits insulin-induced delivery of NMDA receptors to the cell surface (Skeberdis et al., 2001). Neurons treated with active BoNT A ( $1 \mu \mathrm{g} / \mathrm{ml}$, to block exocytosis) or heat-inactivated BoNT A (negative control) for $30 \mathrm{~min}$ were incubated in hypertonic sucrose $(0.45 \mathrm{M}$ for $20 \mathrm{~min}$, to block clathrin-mediated endocy- 
A GluR1 (green)+synaptophysin (red)
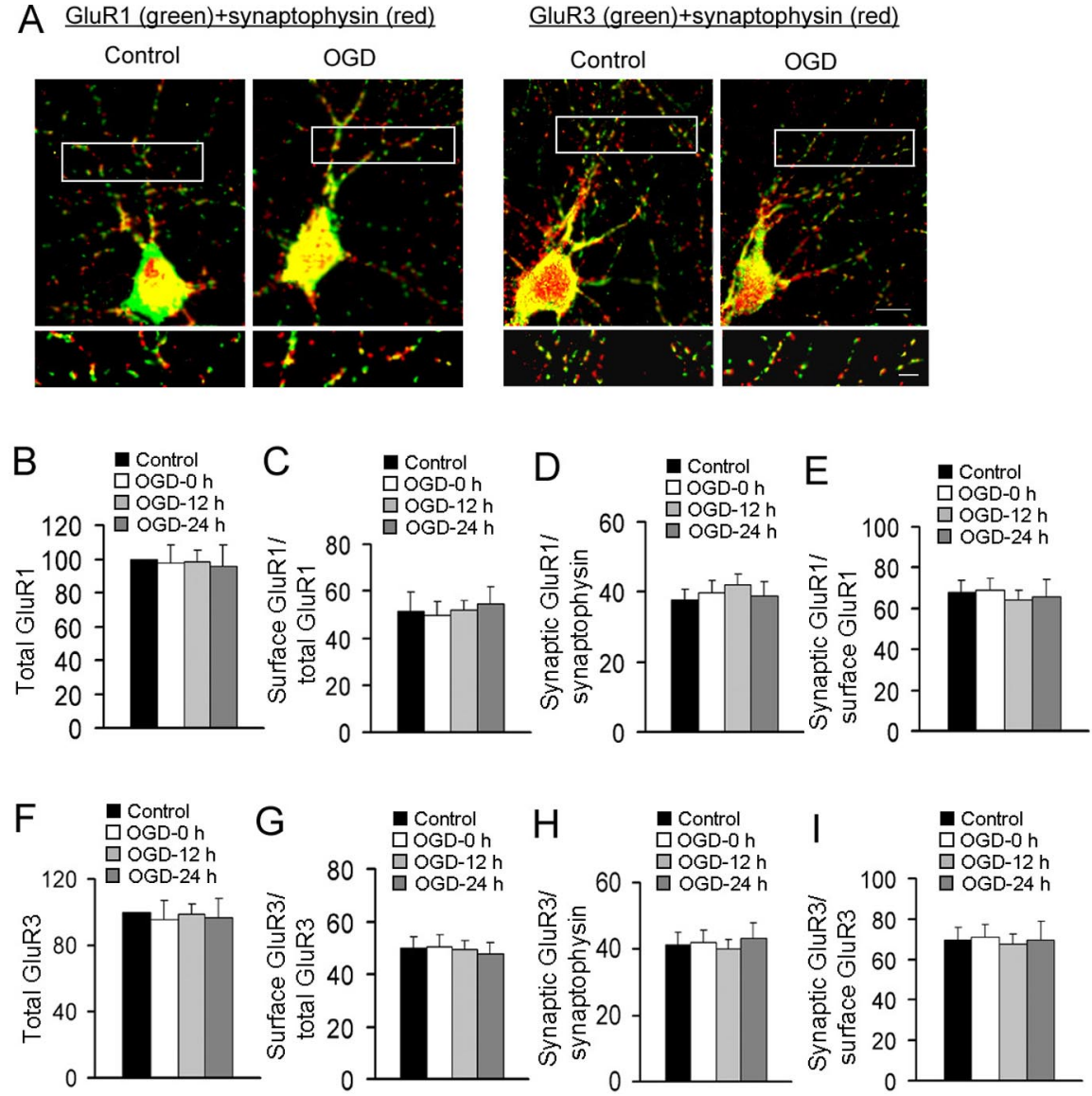

Figure 3. OGD does not significantly alter GluR1 and GluR3 surface expression at synaptic sites. $\boldsymbol{A}$, Representative images showing juxtaposition of GluR1 and GluR3 puncta with synaptophysin puncta in control and experimental hippocampal neurons in culture at $24 \mathrm{~h}$ after $0 \mathrm{GD}$. Higher-magnification images are of boxed areas indicated in the lower-magnification images. Scale bars: lower-magnification images, $15 \mu \mathrm{m}$; higher-magnification images, $5 \mu \mathrm{m} . \boldsymbol{B}, \boldsymbol{F}, 0 \mathrm{GD}(20 \mathrm{~min})$ does not significantly alter total GluR1 $(\boldsymbol{B})$ or GluR3 $(\boldsymbol{F})$ protein expression assessed at 0,12 , and $24 \mathrm{~h}$ after $0 \mathrm{GD}(\boldsymbol{B}, n=6$ for each group, $p>0.05 ; \boldsymbol{F}, n=6$ for each group, $p>0.05)$. $C, G, 0 G D$ does not detectably alter $G$ luR1 $(\boldsymbol{C})$ and $G$ luR3 $(\boldsymbol{G})$ surface expression, as assessed by colorimetric assay $(C, n=6$ for each group, $p>0.05 ; G, n=6$ for each group, $p>0.05)$. $\boldsymbol{D}, \boldsymbol{H}$, Quantification of the percentage of synaptophysinpositive synapses containing GluR1 $(\boldsymbol{D})$ or GluR3 $(\boldsymbol{H})$ puncta in control and $0 \mathrm{GD}$ neurons $(\boldsymbol{D}, n=25,25,32$, and 28 , respectively, per group, $p>0.05 ; \boldsymbol{H}, n=30,29,30$, and 27, respectively, per group, $p>0.05)$. $\boldsymbol{E}, \boldsymbol{I}$, Quantification of the percentage of surface GluR1 $(\boldsymbol{E})$ or GluR3 (I) puncta that are juxtaposed with synaptophysin puncta in control and OGD neurons $(\boldsymbol{E}, n=26,27,29$, and 24 , respectively, per group, $p>0.05 ; I, n=26$ for each group, $p>0.05$ ).

tosis) and then subjected to OGD (20 min). Total, surface, and synaptic GluR1 and GluR3 expression were monitored by immunofluorescence at $0 \mathrm{~h}$ after OGD. Active BoNT A did not significantly alter total GluR1 or GluR3 expression, as assessed by colorimetric assays (Fig. 6B,G). However, the toxin completely blocked the OGD-induced increase in surface and synaptic expression of GluR1 and GluR3 subunits in neurons pretreated with hypertonic sucrose (Fig. 6A, $C-F, H-J$ ). BoNT A produced little or no effect on constitutive expression of surface and synaptic GluR1 or GluR3 (Fig. 6A,C-F,H-J). However, BoNT A treatment reduced surface and synaptic expression of GluR1 and GluR3 subunits in OGD-insulted neurons (data not shown). These data indicate that OGD promotes insertion of GluR1 and GluR3 subunits via SNARE-dependent exocytosis at hippocampal synapses.

Collectively, these data suggest a model whereby OGD promotes the retrieval of GluR2-containing AMPARs from synaptic sites and their replacement by delivery of GluR2-lacking AMPARs (GluR1/GluR3 heteromers or GluR1 and GluR3 homomers) at synaptic sites.
OGD reduces association of GluR2 with $\mathrm{ABP}$ and enhances its association with PICK1

To examine molecular mechanisms mediating the replacement of GluR2containing AMPARs by GluR2-lacking AMPARs at synaptic sites of insulted neurons, we examined interactions between GluR2 and PICK1 or ABP by coimmunoprecipitation. Association of glutamate receptor-interacting protein (GRIP)/ABP with GluR2 has been shown to localize GluR2-containing AMPARs at hippocampal synapses (Osten et al., 2000; Seidenman et al., 2003). During activation, $\mathrm{PKC} \alpha$ is transported by PICK1 to spines, in which PKC $\alpha$ phosphorylates GluR2 and the phosphorylated GluR2 is released from the GRIP/ABP complex (Lu and Ziff, 2005). PICK1 then binds to phosphorylated GluR2 and triggers endocytosis of the GluR2/PICK1 complex (Matsuda et al., 1999; Chung et al., 2000; Osten et al., 2000; Perez et al., 2001; Seidenman et al., 2003). Moreover, PKC-dependent interactions of GluR2 with GRIP/ABP and PICK1 are required for an exchange of synaptic GluR2-containing AMPARs to GluR2-lacking AMPARs at hippocampal synapses (Terashima et al., 2004).

We showed that immunoprecipitation with an antibody to GluR2 resulted in coprecipitation of PICK1 and ABP in control neurons (Fig. $7 A, B$ ). The level of coprecipitated PICK1 was significantly increased, assessed immediately after OGD (Fig. 7A). In contrast, the level of coprecipitated ABP was markedly decreased after OGD (Fig. 7B). The PKC inhibitor GÖ 6976 [12-(2-cyanoethyl)-6,7,12,13-tetrahydro-13-methyl-5-oxo-5H-indolo[2,3a]pyrrolo[3,4-c] carbazole] $(0.1 \mu \mathrm{M}$, specific inhibitor of $\mathrm{PKC} \alpha$ and $\mathrm{PKC} \beta$ ) blocked the OGD-induced increase in association of GluR2 with PICK1 and dissociation from $\mathrm{ABP}$, consistent with a requirement for PKC activation in the interactions of GluR2 with PICK1 and $\mathrm{ABP}$ (Fig. $7 A, B$ ). In independent control experiments, the abundance of GluR2, PICK1, and ABP in the input was invariant, as was the abundance of immunoprecipitated PICK1 and ABP in control and OGD neurons (Fig. $7 A, B$ ). In contrast, neither PICK1 nor ABP coimmunoprecipitated with an antibody to the NMDA receptor subunit NR1 (Fig. 7C), indicating the specificity of the interaction with GluR2. These findings are consistent with a model whereby the OGD-induced switch of GluR2-containing AMPARs to GluR2-lacking AMPARs is triggered by PKCdependent interactions of GluR2 with PICK1 and ABP at hippocampal synapses.

OGD results in increased expression of functional GluR2lacking AMPARs at postsynaptic membrane

The results thus far show that GluR2-lacking AMPARs are selectively targeted at or near synaptic sites after OGD-induced removal of GluR2-containing AMPARs. Because colocalization of 
AMPAR subunit immunofluorescence with synaptophysin immunofluorescence does not distinguish synaptic versus perisynaptic receptor number and cannot afford a measure of functional receptors, we recorded AMPAR-mEPSCs. We performed whole-cell patch-clamp recording of AMPAR-mEPSCs in control and experimental neurons subjected to OGD at 0 , 12 , and $24 \mathrm{~h}$ after insult. OGD did not significantly alter the AMPAR-mEPSC frequency (Fig. $8 A, C, E$ ) but increased AMPAR-mEPSC amplitudes and the sensitivity of AMPAR-mEPSC amplitudes to Naspm (Fig. $8 A, B, D$ ), a subtype-selective blocker of GluR2-lacking AMPARs (Blaschke et al., 1993; Koike et al., 1997; Noh et al., 2005). In insulted neurons, Naspm (20 $\mu \mathrm{M})$ reduced the amplitude of AMPARmEPSCs, assessed at 0,12 , and $24 \mathrm{~h}$ after injury, whereas in control neurons, it did not significantly reduce the amplitude of AMPAR-mEPSCs (Fig. 8A,D). Moreover, pretreatment with hypertonic sucrose further enhanced the OGD-induced increase in AMPAR-mEPSC amplitude at $0 \mathrm{~h}$ after OGD (control, $18.8 \pm 2.05$ pA; OGD, $24.3 \pm 2.39 \mathrm{pA}, p<0.05$, difference from control; sucrose plus OGD, $29.1 \pm 3.16$ $\mathrm{pA}, p<0.05$, difference from OGD; $n=7$ for each group). Consistent with its ability to block the interaction of GluR2 with PICK1 and ABP, the PKC inhibitor GÖ $6976(0.1 \mu \mathrm{M})$ blocked the OGD-induced increase of AMPAR-mEPSC amplitudes and the enhanced sensitivity of AMPARmEPSCs (Fig. 8 B,D). These results provide functional evidence for the expression of GluR2-lacking AMPARs at hippocampal synapses of insulted neurons and indicate a requirement for PKC-dependent interactions of GluR2 with PICK1 and ABP in this process.

\section{Discussion}

Regulated AMPAR trafficking at postsynaptic membranes is a mechanism critical to activity-dependent changes in synaptic efficacy. Whereas the role of regulated AMPAR trafficking in synaptic plasticity under physiological conditions is well established, its role in insult-induced synaptic remodeling and/or cell death is less understood. Here we show the novel observation that brief OGD, an in vitro model of global ischemia, promotes redistribution of AMPARs in the postsynaptic membrane, leading to a switch in AMPAR subunit composition at synaptic sites. Ischemic insults promote retrieval of GluR2-containing AMPARs from synaptic sites and facilitate targeting of GluR2-lacking AMPARs to synaptic sites. These events lead to a rapid and longlasting change in synaptic AMPAR subunit composition before alterations in receptor expression or the onset of neuronal death. We further identify mechanisms underlying the trafficking events. The OGD-induced receptor internalization occurs via clathrin-dependent endocytosis and requires PKC activation, association of the GluR2 subunit with PICK1, and dissociation from ABP. Insult-induced delivery of GluR2-lacking AMPARs to synaptic sites occurs via SNARE-dependent exocytosis. These findings implicate regulated AMPAR trafficking and PKC signaling in the switch in AMPAR subunit composition at synapses of post-ischemic neurons.

We further show that AMPARs at synapses of insulted neurons exhibit functional properties of GluR2-lacking AMPARs. OGD causes a rapid and long-lasting increase in the amplitude of AMPA EPSCs and enhanced sensitivity of AMPA currents to the subunit-specific blocker Naspm. Interestingly, Naspm inhibits the amplitude but not the frequency of AMPA mEPSCs. A possible scenario is that ischemia promotes expression of GluR2lacking AMPARs at only a proportion of postsynaptic sites. Thus, Naspm would cause an incomplete "silencing" of synapses containing GluR2-lacking AMPARs. We also show that the OGDinduced changes in AMPA EPSCs require clathrin-mediated receptor endocytosis and $\mathrm{PKC}$ activation, consistent with a role for PKC signaling and PICK1 in the retrieval of GluR2-containing AMPARs from synapses of insulted neurons and their replacement by functional GluR2-lacking AMPARs. These experiments show that ischemic insults promote the targeting of GluR2lacking AMPARs to synapses of hippocampal neurons and implicate regulated AMPAR trafficking in ischemia-induced synaptic remodeling and neuronal injury.

AMPAR trafficking and its role in ischemic neuronal injury Findings in the present study indicate that ischemic insults regulate AMPAR trafficking and targeting to synaptic sites by usurp- 

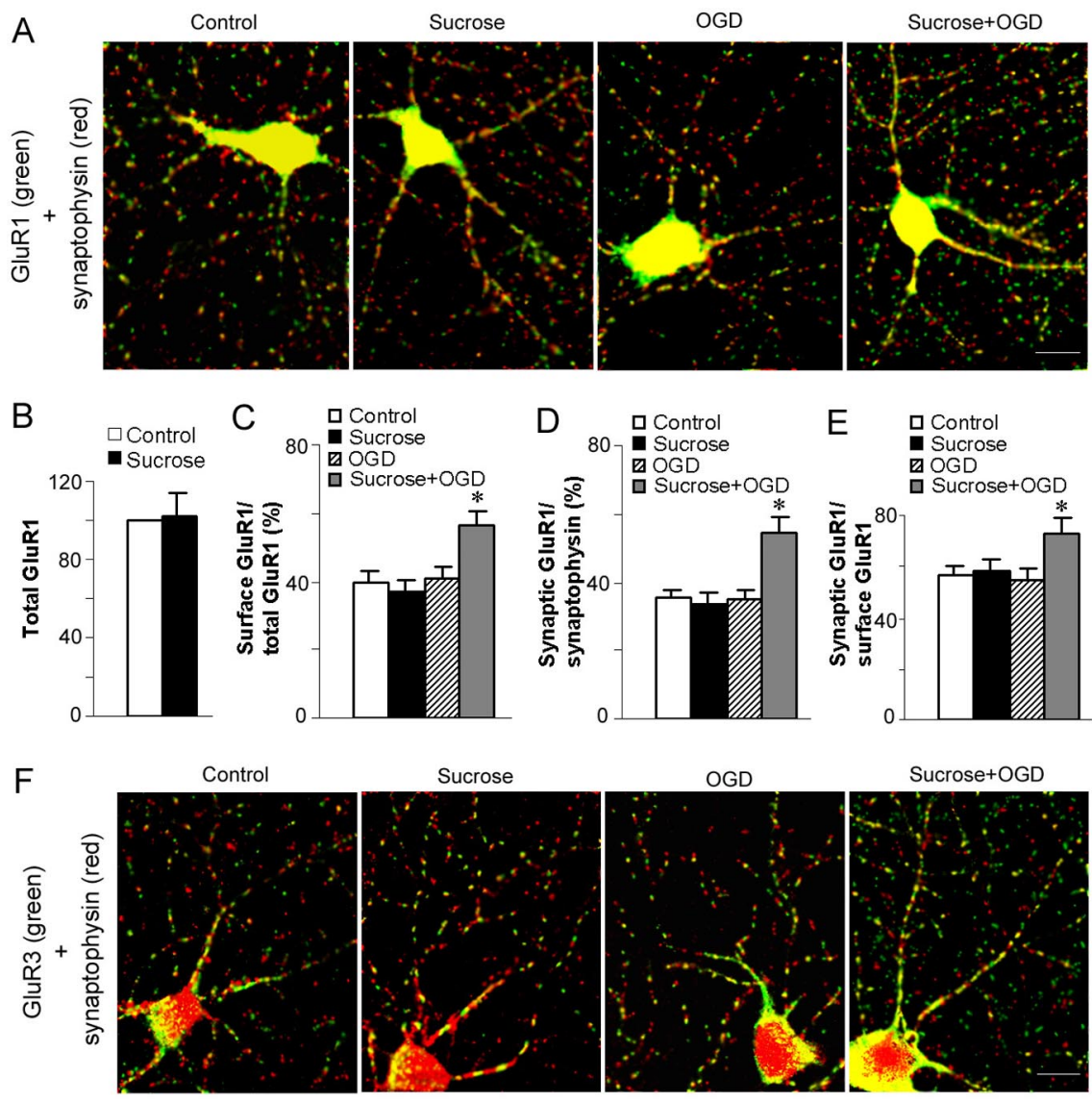

Sucrose+OGD

G

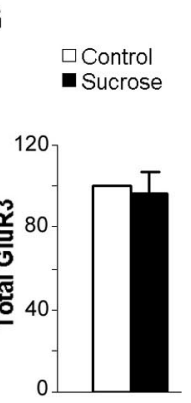
$\mathrm{H}$

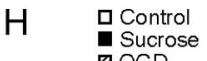
G Sucro OGD

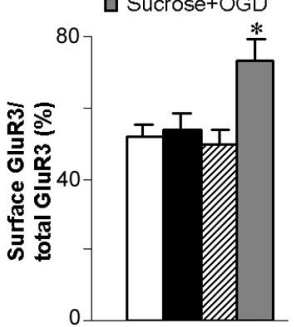

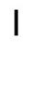
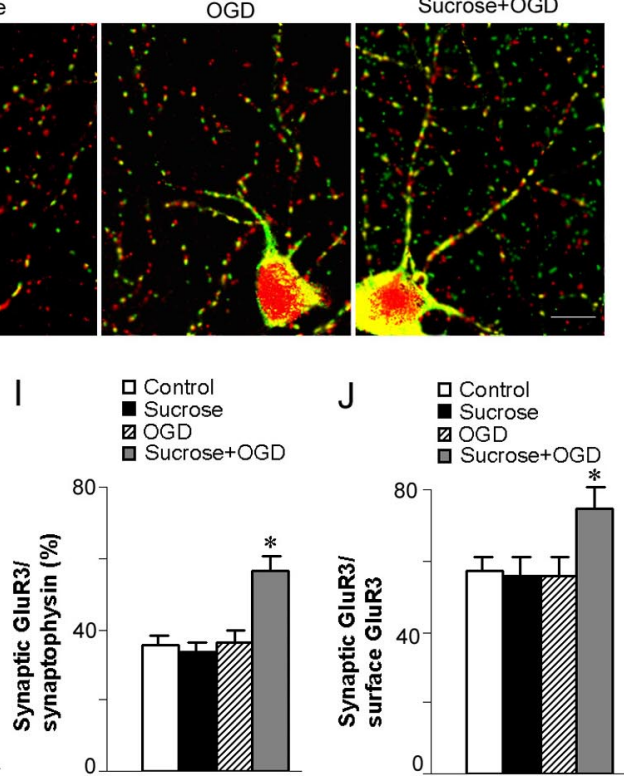

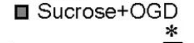

Figure 5. OGD promotes internalization of GluR1 and GluR3 subunits via clathrin-dependent endocytosis pathway. $\boldsymbol{A}, \boldsymbol{F}$, Representative images showing that hypertonic sucrose promotes $0 G D$-induced increase in expression of GluR1 (A) and GluR3 (F) subunits at synaptic sites, assessed at $0 \mathrm{~h}$ after $0 \mathrm{GD}$. Scale bars, $10 \mu \mathrm{m} . \boldsymbol{B}, \boldsymbol{G}$, Hypertonic sucrose does not significantly alter total GluR1 $(\boldsymbol{B})$ and GluR3 $(\boldsymbol{G})$ subunit expression, assessed at $0 \mathrm{~h}$ after $\mathrm{OGD}(\boldsymbol{B}, n=6$ per group, $p>0.05 ; \boldsymbol{G}, n=6$ per group, $p>$ 0.05). $\boldsymbol{C}, \boldsymbol{H}$, Hypertonic sucrose promotes $O G D$-induced increase in surface expression of $G$ luR1 $(\boldsymbol{C})$ and $G$ luR3 $(\boldsymbol{H})$ subunits, assessed at $0 \mathrm{~h}$ after $0 \mathrm{GD}\left(\boldsymbol{C}, n=6\right.$ per group, ${ }^{*} p<0.05 ; \boldsymbol{H}, n=6$ per group, $\left.{ }^{*} p<0.05\right) . \boldsymbol{D}, \boldsymbol{E}, \boldsymbol{I}, \boldsymbol{J}$, Hypertonic sucrose promotes OGD-induced increase in GluR1 $(\boldsymbol{D}, \boldsymbol{E})$ and GluR3 $(\boldsymbol{I}, \boldsymbol{J})$ subunit expression $(\boldsymbol{D}, \boldsymbol{I})$ and fractional expression $(\boldsymbol{E}, \boldsymbol{J})$ at synaptic sites, assessed at $0 \mathrm{~h}$ after $\operatorname{OGD}\left(\boldsymbol{D}, n=22\right.$ per group; $\boldsymbol{E}, n=26$ per group; $I, n=25$ per group; $J, n=23$ per group.; ${ }^{*} p<0.05$ ).

ing mechanisms involved in activity-dependent alterations in receptor trafficking under physiological conditions. Activitydependent alterations in AMPAR number, phosphorylation state, and subunit composition are well established (Carroll et al., 2001). Native AMPARs undergo regulated internalization in response to neuronal activity via the clathrin-coated pit pathway (Beattie et al., 2000; Ehlers, 2000; Lin et al., 2000; Malinow et al., 2000; Man et al., 2000; Xia et al., 2000; Carroll et al., 2001; Sheng and Lee, 2001); once internalized AMPARs undergo postendocytic sorting to recycling versus late lysosomal degradative pathways depending on the activity stimulus (Ehlers, 2000; Lin et al., 2000). In the present study, several findings indicate that AMPAR internalization in response to neuronal insults is mediated via the clathrin pathway. Receptor internalization is blocked by hypertonic sucrose and by chlorpromazine. In addition, neuronal insults promote association of GluR2 with $\beta$-adaptin, a key component of the clathrin pit-mediated pathway.

Subunit-specific functions of AMPARs govern the synaptic delivery and removal of AMPARs in response to neuronal activity (Hayashi et al., 2000; Zhu et al., 2000; Passafaro et al., 2001; Shi et al., 2001). The GluR2 subunit is the primary determinant of activity-driven internalization of AMPARs and controls the post-endocytic sorting of internalized AMPARs to recycling versus late lysosomal degradative pathways (Ehlers, 2000; Lee et al., 2004). In contrast, GluR1 drives AMPARs to postsynaptic sites in response to NMDA receptor stimulation and activation of calcium/calmodulin-dependent protein kinase II, resulting in synaptic potentiation. Findings from the present study suggest that, whereas the GluR2 subunit plays a lead role in mediating OGD-induced retrieval of GluR2-containing AMPARs from synaptic sites, the GluR1 and/or GluR3 subunit is critical to facilitated delivery of GluR2-lacking AMPARs to postsynaptic membrane. The relatively rapid switch in subunit composition is consistent with a role for regulated receptor trafficking. A possible scenario is that a reservoir of vesicular-associated GluR2lacking AMPARs is docked beneath synaptic sites and is strategically "poised" and available for activity or insult-driven insertion. It is also plausible that neuronal insults stabilize GluR2-lacking AMPARs expressed at low density on distal dendrites of CA1/CA3 pyramidal neurons under physiological conditions (Yin et al., 1999) while destabilizing GluR2containing AMPARs. Future studies are warranted to distinguish among these possibilities.

Studies involving cultures of embryonic hippocampal neurons and neonatal hippocampal slices indicate a large intracellular reservoir of AMPARs that can be rapidly inserted in the plasma membrane in response to neuronal activity and play a critical role in synaptogenesis and synaptic remodeling (Huh and Wenthold, 1999; Lee et al., 2001). However, evidence in support of a sizeable pool of intracellular AMPARs and/or its role in AMPAR trafficking in mature hippocampus is, as yet, unclear (Huh and Wenthold, 1999; Lee et al., 2001). Thus, findings in the present study that support a role for regulated receptor trafficking in insulted neurons may more accurately reflect mechanisms of neuronal death in immature brain. Future experiments are warranted to examine a potential role for regulated AMPA recep- 
tor trafficking in ischemia-induced neuronal death in mature brain.

\section{Molecular mechanisms mediating AMPAR redistribution in post-ischemic neurons}

Interactions of AMPARs with receptor trafficking and anchorage proteins are essential to activity-dependent receptor trafficking under physiological conditions (Sheng and Hyoung Lee, 2003). Dissociation of AMPARs from ABP/GRIP and association with PICK1 are critical to receptor internalization (Matsuda et al., 1999; Chung et al., 2000; Osten et al., 2000; Perez et al., 2001; Seidenman et al., 2003; Terashima et al., 2004; Lu and Ziff, 2005) and to exchange of GluR2-lacking AMPARs by GluR2-containing AMPARs at synaptic sites (Gardner et al., 2005; Liu and CullCandy, 2005). The activity-dependent switch in AMPAR subunit composition is associated with an increase in AMPAR EPSC amplitude and rectification index and enhanced sensitivity to polyamine toxin and occurs in a PKC-, PICK1dependent manner (Terashima et al., 2004). Findings in the present study indicate that essentially identical mechanisms underlie insult-induced alterations in synaptic receptor subunit composition and number. Based on experiments in the present study, we propose a model in which OGD promotes AMPAR internalization from synaptic sites via the clathrinmediated pathway (supplemental Fig. 1, available at www.jneurosci.org as supplemental material). Receptor internalization requires activation of $\mathrm{PKC}$, dissociation of GluR2 from the anchorage protein $\mathrm{ABP}$, and association of GluR2 with the receptor trafficking protein PICK1. As GluR2-containing AMPARs are removed from synaptic sites, they are replaced by GluR2-lacking AMPARs, leading to longlasting changes in AMPAR functional properties at synapses of post-ischemic CA1 neurons.

An attractive scenario is that, for GluR2-lacking AMPARs to be delivered, GluR2-containing AMPARs must be removed, consistent with a role for placeholders or "slots" that specify (delimit) AMPAR number at synaptic sites (Barry and Ziff, 2002). Although the molecular identify of the slots is unknown, receptor-binding or scaffolding proteins such as stargazin are thought to participate in slot formation (Schnell et al., 2002). Alternatively, PKC might be critical to SNARE-dependent delivery of AMPARs by analogy to its role in delivery of NMDARs to the plasma membrane (Lan et al., 2001).

\section{Conclusions}

The present study shows the novel finding that mild ischemic insults promote targeting of GluR2-lacking AMPARs to synapses

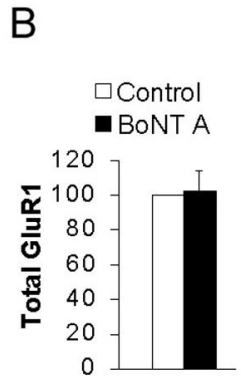

F

G
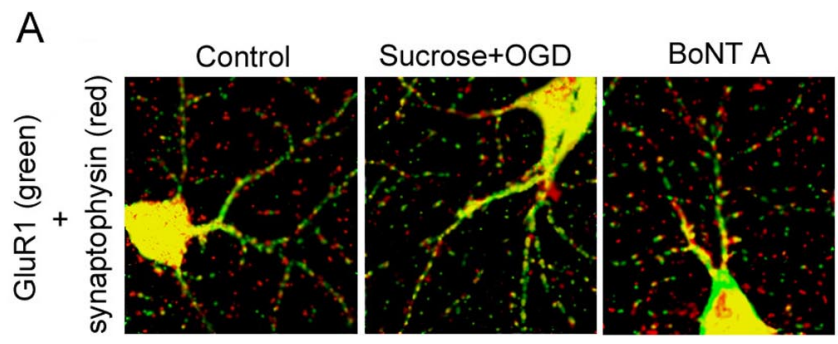

BoNT A+sucrose
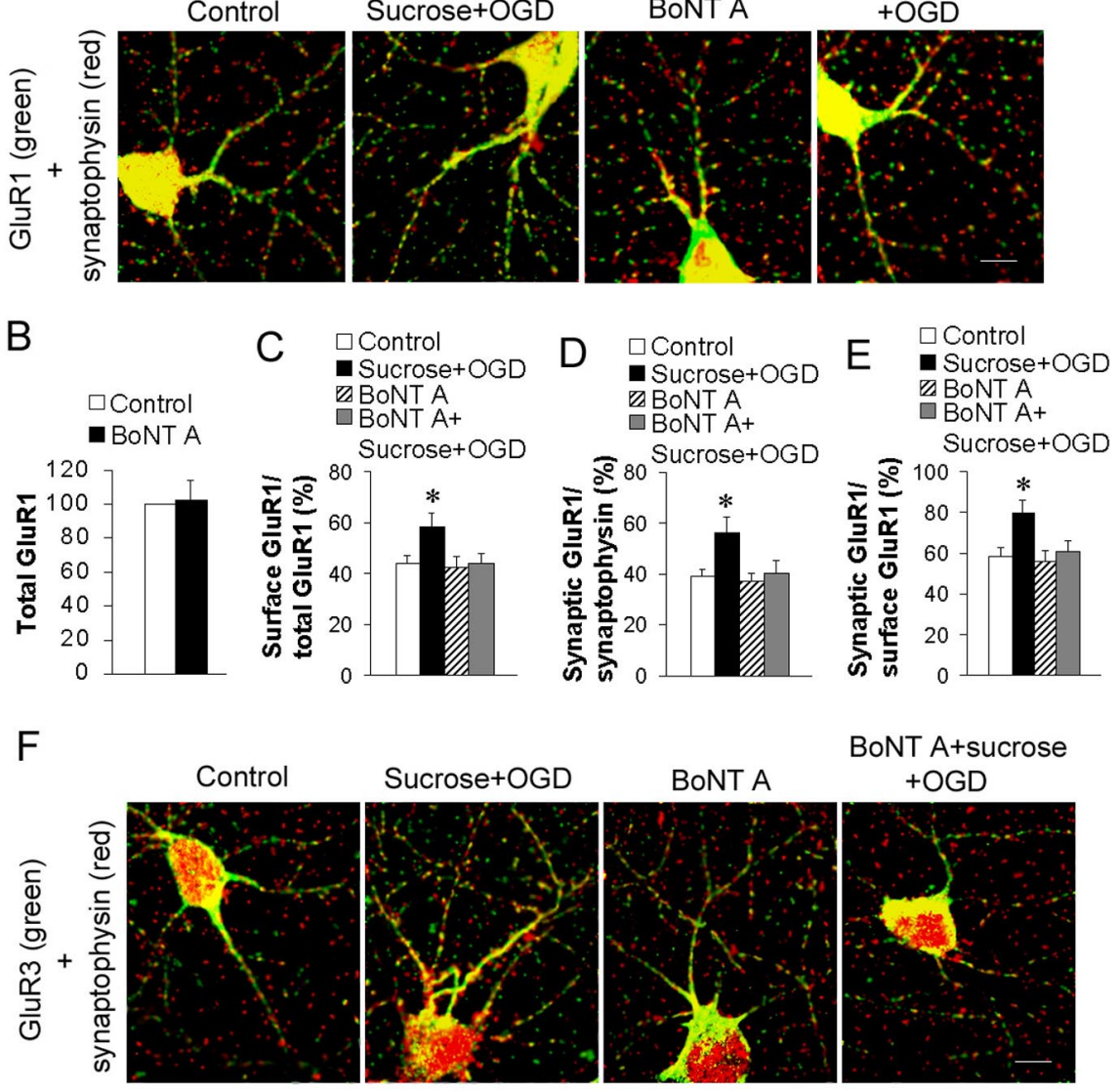

BoNT A+sucrose
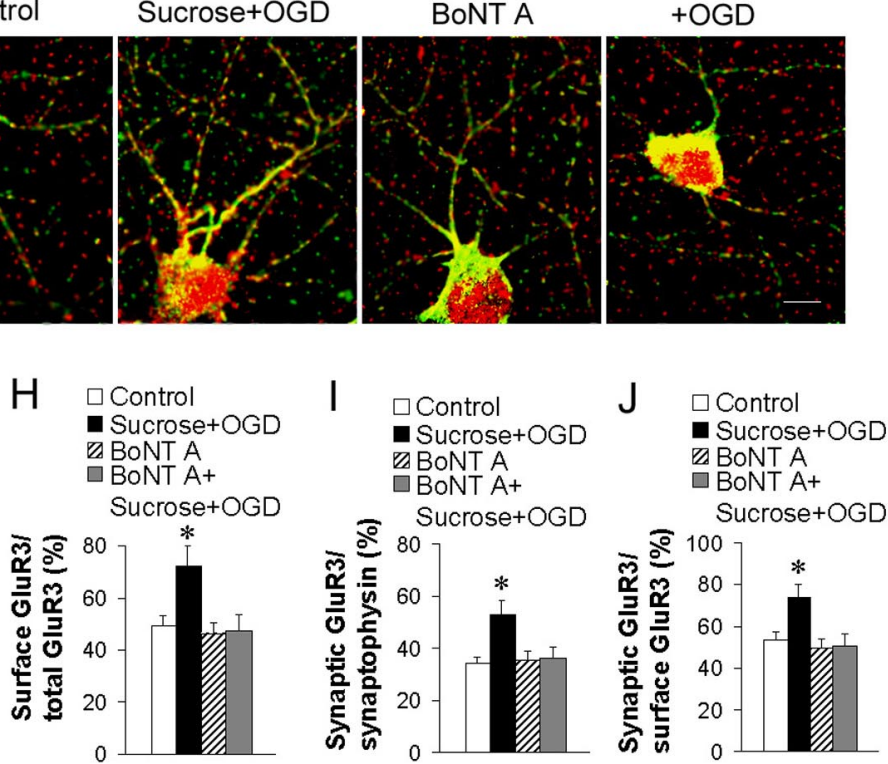

Figure 6. OGD enhances delivery of GluR1 and GluR3 occurs via SNARE-dependent exocytosis. $\boldsymbol{A}, \boldsymbol{F}$, Representative images showing that BoNT A markedly attenuates OGD-induced increase in GluR1 $(\boldsymbol{A})$ and GluR3 $(\boldsymbol{F})$ subunits at synaptic sites in the presence of hypertonic sucrose $(0.45 \mathrm{~m}, 20 \mathrm{~min})$ at $0 \mathrm{~h}$ after $0 \mathrm{GD}$. Scale bar, $10 \mu \mathrm{m}$. $\boldsymbol{B}, \mathbf{G}$, BoNT A does not detectably alter total cellular GluR1 $(\boldsymbol{B})$ and GluR3 $(\boldsymbol{G})$ expression at $0 \mathrm{~h}$ after $0 \mathrm{GD}(\boldsymbol{B}, n=6$ per group, $p>0.05 ; \boldsymbol{G}, n=6$ per group, $p>0.05)$. $\boldsymbol{C}, \boldsymbol{H}$, BoNT A blocks OGD-induced increase of GluR1 $(\boldsymbol{C})$ and GluR3 $(\boldsymbol{H})$ surface expression in the presence of hypertonic sucrose at $0 \mathrm{~h}$ after OGD (C, $n=6$ per group, ${ }^{*} p<0.05 ; \boldsymbol{H}, n=6$ per group, $\left.{ }^{*} p<0.05\right)$. $\boldsymbol{D}, \boldsymbol{E}, \boldsymbol{I}, \mathbf{J}$, BoNT A markedly inhibits OGD-induced increase of GluR1 $(\boldsymbol{D}, \boldsymbol{E})$ and GluR3 $(\boldsymbol{I}, \boldsymbol{J})$ synaptic expression in the presence of hypertonic sucrose at $0 \mathrm{~h}$ after $\mathrm{OGD}(\boldsymbol{D}, n=24$ for per group; $\boldsymbol{E}, n=23$ per group; $\boldsymbol{I}, n=27$ per group; $\boldsymbol{J}, n=25$ per group; ${ }^{*} p<0.05$ ).

of post-ischemic CA1 neurons. Whereas severe ischemia promotes GluR2 mRNA and protein downregulation hours or days after ischemia (Giampietro et al., 1992; Gorter et al., 1997; Ying et al., 1997; Optiz et al., 2000; Pellegrini- Tanaka et al., 2000), regulated receptor trafficking rapidly alters synaptic AMPAR subunit composition and function. The finding that total cellular subunit abundance is unchanged as late as $24 \mathrm{~h}$ after insult suggests that regulated receptor trafficking is likely to be an important mechanism governing changes in synaptic AMPAR subunit composition at early times after ischemia. Given that ischemic insults promote targeting of GluR2-lacking AMPARs to synaptic 
A

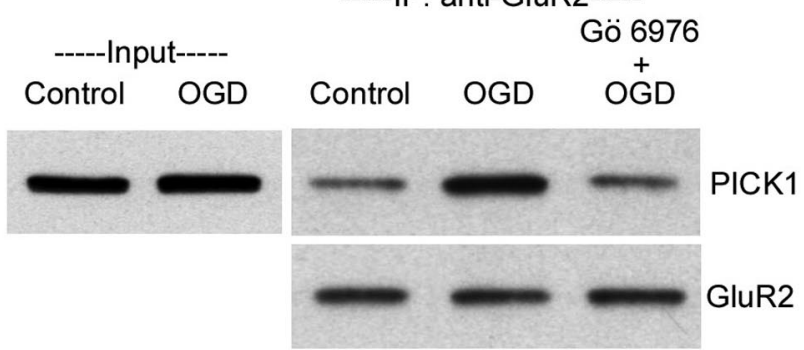

B
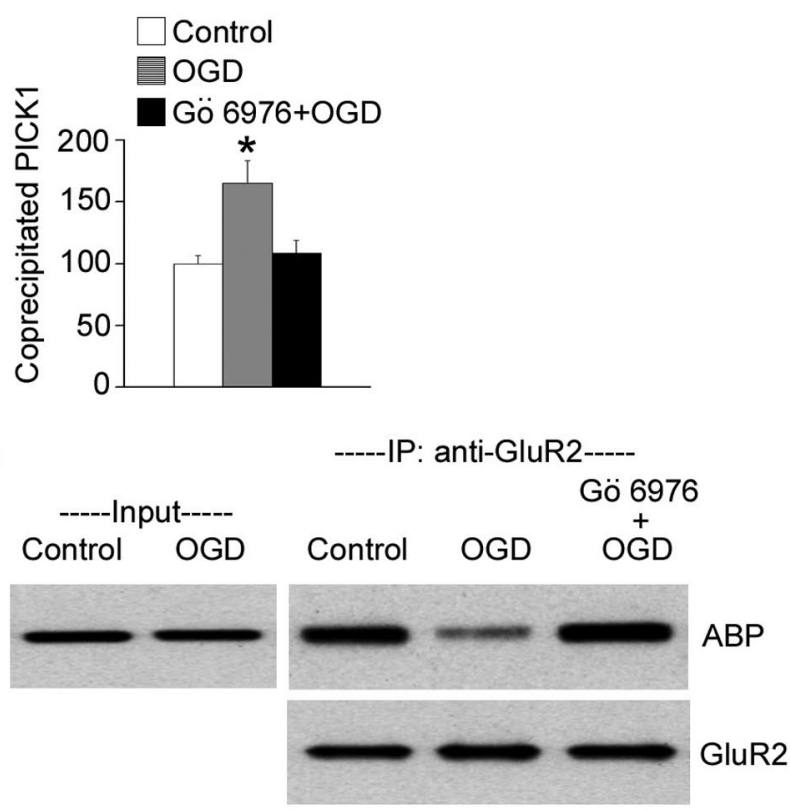

C

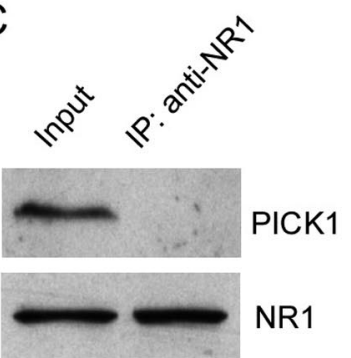

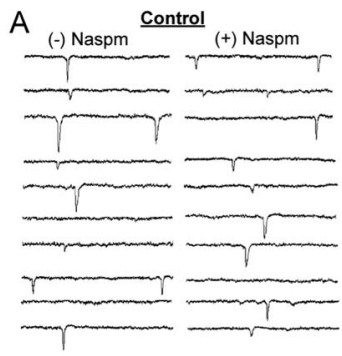
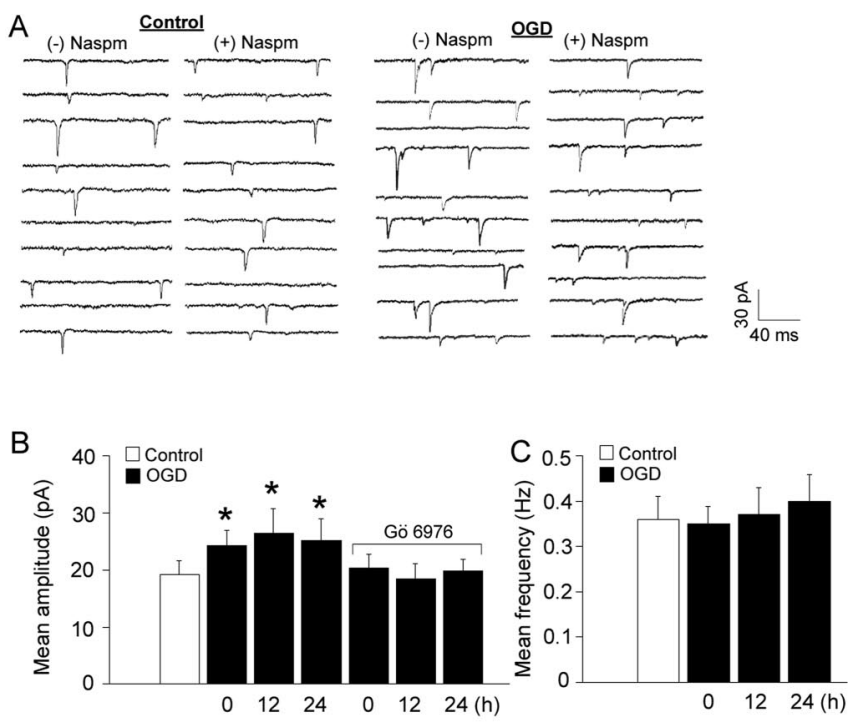

$\mathrm{D}$
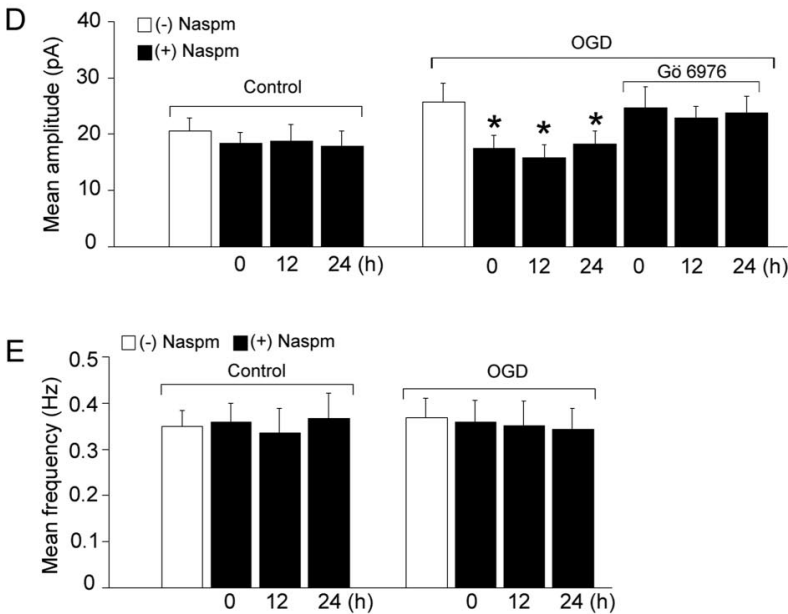

Figure 8. OGD induces increased expression of functional GluR2-lacking AMPA receptors at postsynaptic membrane. $A$, Sample traces of AMPA receptor-mediated mEPSCs recorded in control (left) and OGD-treated (right) neurons at $24 \mathrm{~h}$ after OGD. B, Quantification data indicate that OGD causes significant increases of AMPA-mEPSC amplitudes that are abolished by PKC inhibitor G0̈ $6976(0.1 \mu \mathrm{M})$ at 0,12 , and $24 \mathrm{~h}$ after insults ( $n=9$ per group; $p<0.05)$. C, OGD has no significant effects on the AMPA-mEPSC frequencies ( $n=9$ per group; $p>0.05$ ). Data are normalized to the corresponding control values. $\boldsymbol{D}$, Quantification data indicate that Naspm produces a significantly greater inhibition of the mEPSC amplitudes in OGD versus control neurons, and PKC inhibitor GÖ 6976 prevents the inhibitory effects ( $n=10$ per group; ${ }^{*} p<0.05$ ). Data are normalized to the corresponding control values. $\boldsymbol{E}$, Naspm does not significantly alter the $\mathrm{mEPSC}$ frequency in either the control or OGD neurons ( $n=10$ per group; $p>0.05$ ). Data are normalized to the corresponding control values.
NR1
ABP

Figure 7. OGD enhances the association of GluR2 with PICK1 and reduces its association with ABP in cultured hippocampal neurons. The PKC inhibitor G0̈ 6976 blocks the increase in association with PICK1 and the reduction in association with ABP. $\boldsymbol{A}$, Top, Homogenates prepared from control and OGD hippocampal neurons were precipitated with an anti-GluR2 antibody, and bound protein (PICK1) was detected by immunoblot (IB). Bottom, Summary data for three independent experiments $\left({ }^{*} p<0.05\right)$. $\boldsymbol{B}$, Top, Homogenates prepared from control and OGD hippocampal neurons were precipitated with an anti-GluR2 antibody, and bound protein (ABP) was detected by immunoblot (IB). Bottom, Summary data for three independent experiments $\left({ }^{*} p<0.05\right)$. C, PICK1 or ABP did not coimmunoprecipitate with NR1 subunit of NMDA receptors in hippocampal neurons. sites and suppress GluR2 gene expression in vulnerable hippocampal neurons, these mechanisms could act synergistically to promote cell death. AMPAR-mediated excitotoxicity is thought to play a critical role in many CNS insults (Weiss and Sensi, 2000; Tanaka et al., 2005). Trafficking-mediated alterations in synaptic AMPAR subunit composition and/or number may represent a broad mechanism relevant to synaptic remodeling and neuronal death associated with a number of neurological disorders and diseases.

\section{References}

Barry MF, ZiffEB (2002) Receptor trafficking and the plasticity of excitatory synapses. Curr Opin Neurobiol 12:279-286.

Beattie EC, Carroll RC, Yu X, Morishita W, Yasuda H, von Zastrow M, 
Malenka RC (2000) Regulation of AMPA receptor endocytosis by a signaling mechanism shared with LTD. Nat Neurosci 3:1291-1300.

Blaschke M, Keller BU, Rivosecchi R, Hollmann M, Heinemann S, Konnerth A (1993) A single amino acid determines the subunit-specific spider toxin block of alpha-amino-3-hydroxy-5-methylisoxazole-4-propionate/ kainate receptor channels. Proc Natl Acad Sci USA 90:6528-6532.

Borgdorff AJ, Choquet D (2002) Regulation of AMPA receptor lateral movements. Nature 417:649-653.

Brewer GJ, Torricelli JR, Evege EK, Price PJ (1993) Optimized survival of hippocampal neurons in B27-supplemented Neurobasal, a new serumfree medium combination. J Neurosci Res 35:567-576.

Carroll RC, Beattie EC, von Zastrow M, Malenka RC (2001) Role of AMPA receptor endocytosis in synaptic plasticity. Nat Rev Neurosci 2:315-324.

Choi DW (1995) Calcium: still center-stage in hypoxic-ischemic neuronal death. Trends Neurosci 18:58-60.

Chung HJ, Xia J, Scannevin RH, Zhang X, Huganir RL (2000) Phosphorylation of the AMPA receptor subunit GluR2 differentially regulates its interaction with PDZ domain-containing proteins. J Neurosci 20:7258-7267.

Craig AM, Blackstone CD, Huganir RL, Banker G (1993) The distribution of glutamate receptors in cultured rat hippocampal neurons: postsynaptic clustering of AMPA-selective subunits. Neuron 10:1055-1068.

Dingledine R, Borges K, Bowie D, Traynelis SF (1999) The glutamate receptor ion channels. Pharmacol Rev 51:7-61.

Ehlers MD (2000) Reinsertion or degradation of AMPA receptors determined by activity-dependent endocytic sorting. Neuron 28:511-525.

Gardner SM, Takamiya K, Xia J, Suh JG, Johnson R, Yu S, Huganir RL (2005) Calcium-permeable AMPA receptor plasticity is mediated by subunitspecific interactions with PICK1 and NSF. Neuron 24:903-915.

Geiger JR, Melcher T, Koh DS, Sakmann B, Seeburg PH, Jonas P, Monyer H (1995) Relative abundance of subunit mRNAs determines gating and $\mathrm{Ca}^{2+}$ permeability of AMPA receptors in principal neurons and interneurons in rat CNS. Neuron 15:193-204.

Goldberg MP, Choi DW (1993) Combined oxygen and glucose deprivation in cortical cell culture: calcium-dependent and calcium-independent mechanisms of neuronal injury. J Neurosci 13:3510-3524.

Gorter JA, Petrozzino JJ, Aronica EM, Rosenbaum DM, Opitz T, Bennett MV, Connor JA, Zukin RS (1997) Global ischemia induces downregulation of Glur2 mRNA and increases AMPA receptor-mediated $\mathrm{Ca}^{2+}$ influx in hippocampal CA1 neurons of gerbil. J Neurosci 17:6179-6188.

Hansen SH, Sandvig K, van Deurs B (1993) Clathrin and HA2 adaptors: effects of potassium depletion, hypertonic medium, and cytosol acidification. J Cell Biol 121:61-72.

Hayashi Y, Shi SH, Esteban JA, Piccini A, Poncer JC, Malinow R (2000) Driving AMPA receptors into synapses by LTP and CaMKII: requirement for GluR1 and PDZ domain interaction. Science 287:2262-2267.

Hollmann M, Heinemann S (1994) Cloned glutamate receptors. Annu Rev Neurosci 17:31-108.

Huh KH, Wenthold RJ (1999) Turnover analysis of glutamate receptors identifies a rapidly degraded pool of the $N$-methyl-D-aspartate receptor subunit, NR1, in cultured cerebellar granule cells. J Biol Chem 274:151-157.

Ju W, Morishita W, Tsui J, Gaietta G, Deerinck TJ, Adams SR, Garner CC, Tsien RY, Ellisman MH, Malenka RC (2004) Activity-dependent regulation of dendritic synthesis and trafficking of AMPA receptors. Nat Neurosci 7:244-253.

Kirino T (1982) Delayed neuronal death in the gerbil hippocampus following ischemia. Brain Res 239:57-69.

Koike M, Iino M, Ozawa S (1997) Blocking effect of 1-naphthyl acetyl spermine on $\mathrm{Ca}^{2+}$-permeable AMPA receptors in cultured rat hippocampal neurons. Neurosci Res 29:27-36.

Lan JY, Skeberdis VA, Jover T, Grooms SY, Lin Y, Araneda RC, Zheng X, Bennett MV, Zukin RS (2001) Protein kinase C modulates NMDA receptor trafficking and gating. Nat Neurosci 4:382-390.

Lee SH, Valtschanoff JG, Kharazia VN, Weinberg R, Sheng M (2001) Biochemical and morphological characterization of an intracellular membrane compartment containing AMPA receptors. Neuropharmacology 41:680-692.

Lee SH, Simonetta A, Sheng M (2004) Subunit rules governing the sorting of internalized AMPA receptors in hippocampal neurons. Neuron 43:221-236.

Lin JW, Ju W, Foster K, Lee SH, Ahmadian G, Wyszynski M, Wang YT, Sheng
M (2000) Distinct molecular mechanisms and divergent endocytotic pathways of AMPA receptor internalization. Nat Neurosci 3:1282-1290.

Liu F, Wan Q, Pristupa ZB, Yu XM, Wang YT, Niznik HB (2000) Direct protein-protein coupling enables cross-talk between dopamine D5 and gamma-aminobutyric acid A receptors. Nature 403:274-280.

Liu S, Lau L, Wei J, Zhu D, Zou S, Sun HS, Fu Y, Liu F, Lu Y (2004) Expression of $\mathrm{Ca}^{2+}$-permeable AMPA receptor channels primes cell death in transient forebrain ischemia. Neuron 43:43-55.

Liu SJ, Cull-Candy SG (2005) Subunit interaction with PICK and GRIP controls $\mathrm{Ca}^{2+}$ permeability of AMPARs at cerebellar synapses. Nat Neurosci 8:768-775.

Liu SQ, Cull-Candy SG (2000) Synaptic activity at calcium-permeable AMPA receptors induces a switch in receptor subtype. Nature 405:454-458.

Lu W, Ziff EB (2005) PICK1 interacts with ABP/GRIP to regulate AMPA receptor trafficking. Neuron 47:407-421.

Lu W, Man H, Ju W, Trimble WS, MacDonald JF, Wang YT (2001) Activation of synaptic NMDA receptors induces membrane insertion of new AMPA receptors and LTP in cultured hippocampal neurons. Neuron 29:243-254.

Malenka RC, Nicoll RA (1999) Long-term potentiation: a decade of progress? Science 285:1870-1874.

Malinow R, Malenka RC (2002) AMPA receptor trafficking and synaptic plasticity. Annu Rev Neurosci 25:103-126.

Malinow R, Mainen ZF, Hayashi Y (2000) LTP mechanisms: from silence to four-lane traffic. Curr Opin Neurobiol 10:352-357.

Man HY, Lin JW, Ju WH, Ahmadian G, Liu L, Becker LE, Sheng M, Wang YT (2000) Regulation of AMPA receptor-mediated synaptic transmission by clathrin-dependent receptor internalization. Neuron 25:649-662.

Matsuda S, Mikawa S, Hirai H (1999) Phosphorylation of serine-880 in GluR2 by protein kinase $\mathrm{C}$ prevents its $\mathrm{C}$ terminus from binding with glutamate receptor-interacting protein. J Neurochem 73:1765-1768.

Moga DE, Janssen WG, Vissavajjhala P, Czelusniak SM, Moran TM, Hof PR, Morrison JH (2003) Glutamate receptor subunit 3 (GluR3) immunoreactivity delineates a subpopulation of parvalbumin-containing interneurons in the rat hippocampus. J Comp Neurol 462:15-28.

Montecucco C, Schiavo G (1995) Structure and function of tetanus and botulinum neurotoxins. Q Rev Biophys 28:423-472.

Noh KM, Yokota H, Mashiko T, Castillo PE, Zukin RS, Bennett MV (2005) Blockade of calcium-permeable AMPA receptors protects hippocampal neurons against global ischemia-induced death. Proc Natl Acad Sci USA 102:12230-12235.

Opitz T, Grooms SY, Bennett MV, Zukin RS (2000) Remodeling of alphaamino-3-hydroxy-5-methyl-4-isoxazole-propionic acid receptor subunit composition in hippocampal neurons after global ischemia. Proc Natl Acad Sci USA 97:13360-13365.

Osten P, Khatri L, Perez JL, Kohr G, Giese G, Daly C, Schulz TW, Wensky A, Lee LM, Ziff EB (2000) Mutagenesis reveals a role for ABP/GRIP binding to GluR2 in synaptic surface accumulation of the AMPA receptor. Neuron 27:313-325.

Passafaro M, Piech V, Sheng M (2001) Subunit-specific temporal and spatial patterns of AMPA receptor exocytosis in hippocampal neurons. Nat Neurosci 4:917-926.

Pellegrini-Giampietro DE, Zukin RS, Bennett MV, Cho S, Pulsinelli WA (1992) Switch in glutamate receptor subunit gene expression in CA1 subfield of hippocampus following global ischemia in rats. Proc Natl Acad Sci USA 89:10499-10503.

Peng PL, Zhong X, Tu W, Soundarapandian MM, Molner P, Zhu D, Lau L, Liu S, Liu F, Lu Y (2006) ADAR2-dependent RNA editing of AMPA receptor subunit GluR2 determines vulnerability of neurons in forebrain ischemia. Neuron 49:719-733.

Perez JL, Khatri L, Chang C, Srivastava S, Osten P, Ziff EB (2001) PICK1 targets activated protein kinase Calpha to AMPA receptor clusters in spines of hippocampal neurons and reduces surface levels of the AMPAtype glutamate receptor subunit 2. J Neurosci 21:5417-5428.

Pulsinelli WA, Brierley JB, Plum F (1982) Temporal profile of neuronal damage in a model of transient forebrain ischemia. Ann Neurol 11:491-498.

Schmid SL (1997) Clathrin-coated vesicle formation and protein sorting: an integrated process. Annu Rev Biochem 66:511-548.

Schnell E, Sizemore M, Karimzadegan S, Chen L, Bredt DS, Nicoll RA (2002) 
Direct interactions between PSD-95 and stargazin control synaptic AMPA receptor number. Proc Natl Acad Sci USA 99:13902-13907.

Seidenman KJ, Steinberg JP, Huganir R, Malinow R (2003) Glutamate receptor subunit 2 Serine 880 phosphorylation modulates synaptic transmission and mediates plasticity in CA1 pyramidal cells. J Neurosci 23:9220-9228.

Sheng M, Lee SH (2001) AMPA receptor trafficking and the control of synaptic transmission. Cell 105:825-828.

Sheng M, Hyoung Lee S (2003) AMPA receptor trafficking and synaptic plasticity: major unanswered questions. Neurosci Res 46:127-134.

Shi S, Hayashi Y, Esteban JA, Malinow R (2001) Subunit-specific rules governing AMPA receptor trafficking to synapses in hippocampal pyramidal neurons. Cell 105:331-343.

Skeberdis VA, Lan J, Zheng X, Zukin RS, Bennett MV (2001) Insulin promotes rapid delivery of $N$-methyl-D-aspartate receptors to the cell surface by exocytosis. Proc Natl Acad Sci USA 98:3561-3566.

Snyder EM, Philpot BD, Huber KM, Dong X, Fallon JR, Bear MF (2001) Internalization of ionotropic glutamate receptors in response to $\mathrm{mGluR}$ activation. Nat Neurosci 4:1079-1085.

Tanaka H, Grooms SY, Bennett MV, Zukin RS (2000) The AMPAR subunit GluR2: still front and center-stage. Brain Res 886:190-207.

Terashima A, Cotton L, Dev KK, Meyer G, Zaman S, Duprat F, Henley JM, Collingridge GL, Isaac JT (2004) Regulation of synaptic strength and AMPA receptor subunit composition by PICK1. J Neurosci 24:5381-5390.

Tsubokawa H, Oguro K, Masuzawa T, Nakaima T, Kawai N (1995) Effects of a spider toxin and its analogue on glutamate-activated currents in the hippocampal CA1 neuron after ischemia. J Neurophysiol 74:218 -225.

Verdoorn TA, Burnashev N, Monyer H, Seeburg PH, Sakmann B (1991) Structural determinants of ion flow through recombinant glutamate receptor channels. Science 252:1715-1718.

Wan Q, Man HY, Braunton J, Wang W, Salter MW, Becker L, Wang YT (1997a) Modulation of $\mathrm{GABA}_{\mathrm{A}}$ receptor function by tyrosine phosphorylation of $\beta$ subunits. J Neurosci 17:5062-5069.

Wan Q, Xiong ZG, Man HY, Ackerley CA, Braunton J, Lu WY, Becker LE,
MacDonald JF, Wang YT (1997b) Recruitment of functional GABA(A) receptors to postsynaptic domains by insulin. Nature 388:686-690.

Wang LH, Rothberg KG, Anderson RG (1993) Mis-assembly of clathrin lattices on endosomes reveals a regulatory switch for coated pit formation. J Cell Biol 123:1107-1117.

Weiss JH, Sensi SL (2000) $\mathrm{Ca}^{2+}-\mathrm{Zn}^{2+}$ permeable AMPA or kainate receptors: possible key factors in selective neurodegeneration. Trends Neurosci 23:365-371.

Wenthold RJ, Petralia RS, Blahos J, II, Niedzielski AS (1996) Evidence for multiple AMPA receptor complexes in hippocampal CA1/CA2 neurons. J Neurosci 16:1982-1989.

Xia J, Chung HJ, Wihler C, Huganir RL, Linden DJ (2000) Cerebellar longterm depression requires PKC-regulated interactions between GluR2/3 and PDZ domain-containing proteins. Neuron 28:499-510.

Yin HZ, Sensi SL, Carriedo SG, Weiss JH (1999) Dendritic localization of $\mathrm{Ca}^{2+}$-permeable AMPA/kainate channels in hippocampal pyramidal neurons. J Comp Neurol 409:250-260.

Yin HZ, Sensi SL, Ogoshi F, Weiss JH (2002) Blockade of $\mathrm{Ca}^{2+}$-permeable AMPA/kainate channels decreases oxygen-glucose deprivation-induced $\mathrm{Zn}^{2+}$ accumulation and neuronal loss in hippocampal pyramidal neurons. J Neurosci 22:1273-1279.

Ying HS, Weishaupt JH, Grabb M, Canzoniero LMT, Sensi SL, Sheline CT, Monyer H, Choi DW (1997) Sublethal oxygen-glucose deprivation alters hippocampal neuronal AMPA receptor expression and vulnerability to kainate-induced death. J Neurosci 17:9536-9544.

Zhu JJ, Esteban JA, Hayashi Y, Malinow R (2000) Postnatal synaptic potentiation: delivery of GluR4-containing AMPA receptors by spontaneous activity. Nat Neurosci 3:1098-1106.

Zhu JX, Goldoni S, Bix G, Owens RT, McQuillan DJ, Reed CC, Iozzo RV (2005) Decorin evokes protracted internalization and degradation of the EGF receptor via caveolar endocytosis. J Biol Chem 280:32468-32479.

Zukin RS, Jover T, Yokota H, Calderone A, Simionescu M, Lau CG (2004) Molecular and cellular mechanisms of ischemia-induced neuronal death. In: Stroke: pathophysiology, diagnosis, and management (Mohr JP, Choi D, Grotta JC, Weir B, Wolf PA, eds), pp 829-854. Orlando, FL: Harcourt. 